\title{
The difference in the measurement of freeway space in upright sitting position with and without electromyograph
}

\author{
Stevani Monika Halim*, Taufik Sumarsongko*, Aprillia Adenan* \\ *Department of Prosthodontics, Faculty of Dentistry, Padjadjaran University
}

\begin{abstract}
Introduction: Measurement of vertical dimension is very important because improper measurement of vertical dimension may create stomatognatic problem. Electromyography is a tool for recording electrical signals generated from the mechanism of muscle contraction. This study aims to determine the accuracy of measurements of FWS with and without electromyograph. Methods: This research was a descriptive comparative study using purposive sampling methods. Measurements of FWS in an upright sitting position with and without electromyograph were done on 10 students of class 2008 from Faculty of Dentistry, UNPAD who met the criteria. Data were analyzed by $t$ test statistics, showed that there were significant differences in the measurements with and without electromyography in upright sitting position. Results: The mean of FWS measured with electromyography was $2.38 \mathrm{~mm}$ with standard deviation of $0.44 \mathrm{~mm}$, whereas the mean of FWS measured without electromyography was $1.69 \mathrm{~mm}$ with a standard deviation of $0.46 \mathrm{~mm}$. Average FWS in men measured with electromyography was 2.51 $\mathrm{mm}$ with a standard deviation of $0.15 \mathrm{~mm}$, whereas the mean without electromyography was 1.68 $\mathrm{mm}$ with a standard deviation of $0.43 \mathrm{~mm}$. Average FWS in women measured with electromyography was $2.35 \mathrm{~mm}$ with a standard deviation of $0.49 \mathrm{~mm}$, whereas the mean without electromyography was $1.69 \mathrm{~mm}$ with a standard deviation of $0.50 \mathrm{~mm}$. Conclusion: The measurements of FWS with electromyograph in an upright seating position was greater than without electromyography.
\end{abstract}

Keywords: Electromyography, Freeway Space, and Vertical Dimension

\section{INTRODUCTION}

Loss of teeth, especially occlusal stop, causes changes in centric relations and vertical dimensions. During jaw movement the mandible attempts to contact with the upper jaw, therefore the absence of teeth in both jaws will result in the loss of centric occlusion.

The vertical relationship between the maxilla and mandible is determined by vertical dimension and the horizontal relationship is determined by centric relation.There are two stages in making artificial teeth, namely the laboratory stage and clinical stage. One important clinical stage is the determination of the vertical dimension. Vertical dimension is a measurement of the distance between the maxilla and mandible in centric occlusion and in the physiological state. ${ }^{1}$

The determination of vertical dimension is critical in relation to facial shape, a person's aesthetic and denture function. ${ }^{1}$ In the case where there is loss of anterior teeth and or overall loss of one side of the jaw, operators often experience difficulties because vertical dimensions, rest 
position, and interocclusal distances undergo changes that greatly affect vertical dimensions and centric relations ${ }^{3,4}$

There are two types of vertical dimension, namely vertical dimension at centric occlusion and vertical dimension at rest. Vertical dimensions at centric occlusion in edentulous mouth is determined by the formula of physiological vertical dimension minus freeway space. Freeway space is the vertical distance between the maxillary and mandibular teeth at rest, in the book written by Piekartz (2001), the measurement of freeway space is between 2-5 mm. ${ }^{5}$ The accuracy of the freeway space is essential for esthetics, avoiding pain in temporomandibular joints, and preventing alveolar bone resection. ${ }^{6}$

Electromyography is a tool for recording electrical signals generated from the mechanism of muscle contraction. Electrical signals are detected at the stage where calcium ions produce tensile strength between actin filaments and myosins which cause the two filaments to shift to each other resulting in a contractionary process. Since electromyography is an electrodiagnostic technique for recording electrical signals on skeletal muscles by using electrode, elevated electromyographic signals show hyperactivity in mastication muscles at rest and decrease during maxillary contraction activity 78196

The electrodes used may be surface electrodes attached to the surface of the skin or needle electrodes inserted into the skeletal muscle to study their electrical potentials. 1096 The position of the head during the measurement of vertical dimensional is influenced by the force of gravity, therefore affecting the measurement result of freeway space. ${ }^{3}$ Based on information on the difference of high freeway space and the usefulness of electromyographic tools, the authors are motivated to investigate the difference in measurement of freeway space in upright sitting position with and without using electromyography. The purpose of this study is to determine whether there are differences in the measurement of freeway space in upright sitting positions without EMG and with EMG, to determine whether there are differences in the measurement of freeway space in upright sitting position without EMG between men and women, and to know is there any difference in the measurement results of the freeway space in upright sitting position with the EMG between males and females.

\section{METHODS}

The type of research used is descriptive comparative. This research method is conducted with the main purpose to describe the difference in the measurement of freeway space in upright position with and without electromyography11 (Notoatmodjo, 2010). The population in this research is the students of batch 2008 from Faculty of Dentistry Universitas Padjadjaran in Bandung. The sample in this study is selected by using purposive sampling method. This method of sampling that is done based on certain criteria made by the researcher11 (Notoatmodjo, 2010), following the criteria the age ranged from 19-23 years, with the condition of not using autonomic muscle drug, not being in orthodontic treatment, with complete dentition or maximum loss of 2 teeth bilaterally on the same jaw, class I Angle Classification, no premature contact, no abrasion / excision on all occlusal surfaces, and no temporomandibular disorder.

\section{RESULTS}

The research was conducted on 10 students of FKG UNPAD class of 2008 with certain criteria, at the laboratory of Faculty of Electrical Department of Biomedical Road Ganesha no. 10 on March 26 to April 29, 2012, the measurement of freeway space was measured in upright sitting position without leaning, with and without using the electromyographic tool. Freeway space measurements are obtained by reducing the vertical dimension during physiological position by vertical dimension at centric occlusion.

Table 1. Mean of Freeway Space Measurement in Upright Sitting Position with and without Electromyography

\begin{tabular}{cccc}
\hline \multicolumn{2}{c}{$\begin{array}{c}\text { Freeway space without } \\
\text { electromyography }(\mathrm{mm})\end{array}$} & \multicolumn{2}{c}{$\begin{array}{c}\text { Freeway space with elec- } \\
\text { tromyography }(\mathrm{mm})\end{array}$} \\
\hline Mean & $\begin{array}{c}\text { Standard } \\
\text { Deviation }\end{array}$ & Mean & $\begin{array}{c}\text { Standard } \\
\text { Deviation }\end{array}$ \\
1.69 & 0.46 & 2.38 & 0.44 \\
\hline
\end{tabular}

electromyography was $2.38 \mathrm{~mm}$ with standard deviation $0.44 \mathrm{~mm}$. After obtaining the mean freeway space measured with and without electromy- 
ography, the differences in mean value, standard deviation, and $t$ arithmetic measurement of freeway space with and without electromyography can be obtained. The results of these calculations

Table 2. Differences in Mean Values of Freeway Space in Upright Sitting position with and without Electromyography

\begin{tabular}{ccc}
\hline $\mathrm{N}$ & Measurement & Freeway Space $(\mathrm{mm})$ \\
\hline $\mathrm{m} 10$ & Mean Value & 0.69 \\
& Standard Deviation & 0.38 \\
& $\mathrm{t}$ calculated & 5.738 \\
$\mathrm{t}$ table & 2.262 \\
\hline
\end{tabular}

can be seen in Table 2. In Table 2, the difference in mean value of freeway space measurement in upright sitting position with and without electromyography was $0,69 \mathrm{~mm}$ with standard deviation $0,38 \mathrm{~mm}$ and based on statistical analysis $\mathrm{t}$ count equal to $5,738 \mathrm{~mm}$. Data of research result collected and analyzed using $t$ test statistics for paired data and independent data. Hypothesis test using the initial hypothesis and alternative hypothesis for measurement of freeway space in upright sitting position with and without electromyography is: $\mathrm{HO}: \mathrm{B}=0$; There is no difference in the measurement results of freeway space between not using electromyography and by using electromyography. $\mathrm{H} 1: \mathrm{B} \neq 0$; There is a difference in the measurement results of freeway space between not using electromyography and by using $\mathrm{HO}$ rejected if test criteria | t calculated $\mid>t$ table, otherwise $\mathrm{H} 1$ is accepted. reject $\mathrm{HO}$ If the ttable is obtained from the distribution list $t$ with $\mathrm{dk}(\mathrm{n}-1)$. Based on statistical analysis by using paired data test formula $t$ obtained from the result of mea-

Table 3. Independent $\mathrm{t}$ Test of Freeway Space between Men and Women without Electromyograph

\begin{tabular}{ccccc}
\hline Gender & Total & Mean $(\mathrm{mm})$ & $\mathrm{t}$ calculated & $\mathrm{t}$ table \\
\hline Female & 8 & 1.69 & & \\
Male & 2 & 1.68 & 0.052 & 1.860 \\
\hline
\end{tabular}

surement of freeway space 5,738 . Test criteria at significant level $\alpha=0.05$ : obtained ttable $=2.262$ : means | tcalculated | measurement of freeway space $>\mathrm{t}$ table, so hypothesis $\mathrm{HO}$ is rejected Table 4.3 shows the difference in mean of freeway space in upright sitting position without electromyography in men of $1.68 \mathrm{~mm}$ and women of $1.69 \mathrm{~mm}$, based on statistical analysis obtained $t$ arithmetic 0.052 . In hypothesis test by using initial hypothesis and alternative hypothesis for measurement of freeway space upright sitting position without electromyography in men and women are: Based on statistical analysis by using paired data t test formula obtained from tcalculated measurement of freeway space 0,052 . Test criteria at significant level $a=0.05$ : obtained ttable $=1.860$ : means । tcalculated | measurement of freeway space $<\mathrm{t}$ table, so hypothesis $\mathrm{HO}$ accepted.

Table 4. Independent t Test Results of Freeway Space between Male and Female with Electromyograph

\begin{tabular}{ccccc}
\hline Gender & Total & Mean $(\mathrm{mm})$ & $\mathrm{t}$ calculated & $\mathrm{t}$ table \\
\hline Female & 8 & 2.35 & & \\
Male & 2 & 2.51 & 0.901 & 1.860 \\
\hline
\end{tabular}

Table 4 shows the mean of freeway space in upright sitting position without electromyography in males was $2.51 \mathrm{~mm}$ and in women was 2.35 $\mathrm{mm}$, based on statistical analysis obtained $\mathrm{t}$ count 0.901 . In hypothesis test by using initial hypothesis and alternative hypothesis for measurement of freeway space upright position with electromyography in men and women.

Based on statistical analysis using paired data test formula $t$ obtained from the result of measurement of freeway space 0.901 . Test criteria at significant level $a=0.05$ : obtained ttable = 1.860: means | tcalculated | measurement of freeway space $<\mathrm{t}$ table, so hypothesis $\mathrm{HO}$ accepted.

\section{DISCUSSION}

From the sample of 10 people, the result of measurement in Table 1 shows that the measurement of freeway space in upright sitting position with electromyography is greater than without electromyography. While using electromyography, it showed that the condition of the chewing muscle is most physiological in the upright sitting position which is why the mean measurement of freeway space with electromyography is greater than the mean measurement of freeway space without electromyography. ${ }^{12}$ In the measurement of freeway space by electromyography, the researcher used surface electromyography, using a parallel-mounted electrode plate to capture the 
contraction signal from the masticatory muscles. To see the activity of a muscle, it requires the installation of two plates on the muscle and one muscle in another muscle but on one region. The electrode plate is attached to the right and left temporalis muscles, two at each side. Similarly, two plates on each right and left masseter muscles, while the neutral electrode of each plate is affixed to the hand. One plate is a positive pole and another one negative, and the neutral electrode serves as a benchmark of the muscle to be studied. If the neutral electrode is not installed, the electromyograph will not be able to record the muscle activity. The result will not be stable nor be in accordance with the actual muscle condition. ${ }^{13}$ Masseter and temporalis muscle play an important role in the opening of the mouth. In addition, the location and shape of the muscles is large enough to make them palpable. Therefore masseter and temporalis muscles were chosen in this study to measure the physiological vertical dimension ${ }^{14}$

In this study, the mean value of freeway space in upright sitting position by using electromyography was $2.38 \mathrm{~mm}$ while without electromyography ws $1.69 \mathrm{~mm}$, hence the difference was $0.69 \mathrm{~mm}$. This shows that the condition of the muscles were not in the most physiological conditions while the physiological vertical dimension was measured without electromyograph, While measuring the physiological vertical dimension, all the muscles involved in opening and closing the mandible are in a minimal tonic contraction state, which serves only to maintain posture. Graphite adds pressure to the mandibular muscles which is why the body position of respondents in this study is upright. ${ }^{4}$ The average measurement of freeway space in upright sitting position with electromyograph was $2.38 \mathrm{~mm}$, the result is in accordance with Boucher (2002) theory that the average freeway space observed in the first premolar region is 2-4 mm. ${ }^{4}$ The average measurement of freeway space in the upright sitting position without the electromyograph was obtained by reducing the physiological vertical dimension by the vertical dimension at centric occlusion. Physiological vertical dimension was obtained by asking the repondent to maintain an upright sitting position and it is measured when the respondent says "emm .." . The average freeway space using this method was
$1.69 \mathrm{~mm}$. The results were not in accordance with the theory of Boucher which states that the freeway space is $2-5 \mathrm{~mm}$. This was probably because the respondents were not in the most relaxed state while pronouncing "em .." during the measurement of the physiological vertical dimension, and they slightly constricted the mandible, resulting in freeway space below $2 \mathrm{~mm}$ while measuring without electromyography.

The dental classification of the subjects in this study was Angle class I. Class I angle classification is an ideal occlusal relationship, where the mesiobuccal cusp tip of the first permanent upper molar occludes with the buccal groove of the first permanent lower molar15 (Foster, 1999). Freeway space occurs in this ideal occlusal relationship without malocclusion. Respondents in this study also had a healthy temporomandibular joint condition. In individuals with Temporo Mandibular Disorder ( TMD, there may be an uneven balance between between the left and right muscles. TMD sufferers do not have balanced or symmetric occlusion.16 (Ardizone, 2010).

From Table 3 and 4, the average measurements of freeway space on males in upright sitting positions with electromyography was $2.51 \mathrm{~mm}$ while in women it was $2.35 \mathrm{~mm}$. According to Johnson (2012), the average measurement of freeway space measured with electromyograph in upright position in men and women is $2-4 \mathrm{~mm}$. According to Guyton (2008), the conditions of muscles in men and women are different due to the influence of gonadal hormone on muscle development. In men, the testes secrete testosterone that cause muscle mass to be 50 percent more than female muscle mass7. Testosterone form more fibers in the masticatory muscles of men, therefore the muscle strength of male is greater than that of female17 (Hellen, 1984). Hence, freeway space in men is larger than that of female.

The $t$ test in this study did not obtain significant differences between measurement of free way space between male and female with and without electromyograph. This is in contrast to the theory. This may be a result of unbalanced number of male and female samples. However, the results showed that there were significant differences in the measurement of freeway space in the upright sitting position with and without electromyograph. 


\section{CONCLUSION}

There were differences in the measurement of freeway space in upright sitting position with and without electromyograph.

\section{REFERENCES}

1. Austin KP, Lnidge EF. Geligi Tiruan Sebagian. CV. Mosby Company: USA. 1957. 167-171 pp

2. Sudarso ISR. Perbedaan Free Way Space pada Anak Balita Suku Jawa dan Cina di Yogyakarta. Yogyakarta: FKG UGM. March 2008;23(1):18

3. Geering $\mathrm{AH}$. Complete Denture and Overdenture Prosthetics. Thieme Med Pub, Inc: New York. 1993. 5 pp.

4. Boucher Dalam CL, Bolender GA, Zarb JD, Hickey. Buku Ajar Prostodonti untuk Pasien tak Bergigi menurut Boucher. Jakarta : EGC. 2002. 207-252 pp.

5. Piekartz HV, Bryden L. Craniofacial Dysfunction and Pain. British: R Ed Professional Pub L.td. 2001. 168 pp.

6. Barros TEP. Electromyographic Study of the Masseter Muscle after Lower Third Molar Surgery. Int J Morphol. 2011;29(1):304-309.

7. Guyton AC, Hall JE. Fisiologi Kedokteran. $11^{\text {th }}$ ed. Jakarta: EGC. 2008. 76-83, 91-106 pp.

8. Wijayanto YN, Hastuti D. Rangkaian Bioamplifier untuk Mendeteksi Sifat Elektris Otot. J Electronica. Jul- Des 2006;2(5):78-85 pp.
9. Ferla A, Silva AM, Corrêa EC. Electrical activity of the anterior temporal and masseter muscles in mouth and nasal breathing children. Braz J Otorhinolaryngol. 2008 Jul-Aug;74(4):588-95. DOI: 10.1016/s1808-8694(15)30608-X

10. Notoatmodjo S. Metode Penelitian Kesehatan. Jakarta: Rineka Cipta. 2010. 18-25 pp.

11. Khoiri M. Tinjauan Aplikasi Elektromiografi dalam Ergonomi. Yogyakarta: Seminar Nasional IV SDM Teknologi Nuklir. 2008.

12. Oh SJ. Clinical Electromyography Nerve Conduction Studies Third Edition. USA: Lippincott Williams and Wilkins. 2003. 34, 118, 152 pp.

13. Lang J. Clinical Anatomy of the Masticatory Apparatus and Peripharyngeal Space. New York. Thieme. 1995. 85-90.

14. Foster TD. Buku Ajar Ortodonsia. $3^{\text {rd }}$ ed. Jakarta: EGC. 1999. 32 pp.

15. Ardizone I, Celemin A, Aneiros F, del Rio J, Sanchez T, Moreno I. Electromyographic study of activity of the masseter and anterior temporalis muscles in patients with temporomandibular joint (TMJ) dysfunction: comparison with the clinical dysfunction index. Med Oral Patol Oral Cir Bucal. Jan 2010;15(1):14-9. DOI: 10.4317/medoral.15.e14

16. Hellen D. Sudarso ISR, Perbedaan Free Way Space pada Anak Balita Suku Jawa dan Cina di Yogyakarta. Yogyakarta: FKG UGM. March 2008;23(1)18. Avaliable from: https://repository.ugm.ac.id/view/year/2011.type.html 